Editorial

\title{
Bloods-An Open Access Journal of Hematology
}

\author{
Shu-Kun Lin 1 \\ MDPI, St. Alban-Anlage 66, CH-4052 Basel, Switzerland; lin@mdpi.com \\ Received: 6 February 2020; Accepted: 6 February 2020; Published: 20 February 2020
}

MDPI has been publishing several medical journals, including the International Journal of Neonatal Screening [1], the Journal of Cardiovascular Development and Disease [2], the Journal of Functional Morphology and Kinesiology [3], the Journal of Personalized Medicine [4], and the fast-growing Journal of Clinical Medicine [5]. We would like to launch one more medical journal—Bloods—as an international journal of hematology. Starting from the chemistry journal Molecules [6], we launched several journals bearing a one-word plural noun as titles, Sensors [7], Energies [8], Nutrients [9], Cells [10], Plants [11], Animals [12], Viruses [13], Forests [14], Foods [15], Catalysts [16], Genes [17], Metals [18], Processes [19], and Microorganisms [20]. Bloods will take this form as the journal title.

Since 2018, MDPI has become the largest publisher of open access articles in DOAJ and, in 2019, the fifth largest publisher of scholarly journals [21]. We provide the best peer review editorial service according to the Publons database this year [22]. Of course, we would like to hear from our authors, reviewers, and academic medical scientists to maintain and improve this fast and rigorous peer review.

We hope you enjoy publishing with us!

Conflicts of Interest: The author declares no conflicts of interest.

\section{References}

1. International Journal of Neonatal Screening website. Available online: https://www.mdpi.com/journal/IJNS.

2. Journal of Cardiovascular Development and Disease website. Available online: https://www.mdpi.com/journal/jcdd.

3. Journal of Functional Morphology and Kinesiology website. Available online: https://www.mdpi.com/journal/jfmk.

4. Journal of Personalized Medicine website. Available online: https://www.mdpi.com/journal/jpm.

5. Journal of Clinical Medicine website. Available online: https://www.mdpi.com/journal/jcm.

6. Molecules website. Available online: https://www.mdpi.com/journal/molecules.

7. Sensors website. Available online: https://www.mdpi.com/journal/Sensors.

8. Energies website. Available online: https://www.mdpi.com/journal/Energies.

9. Nutrients website. Available online: https://www.mdpi.com/journal/Nutrients.

10. Cells website. Available online: https://www.mdpi.com/journal/Cells.

11. Plants website. Available online: https://www.mdpi.com/journal/Plants.

12. Animals website. Available online: https://www.mdpi.com/journal/Animals.

13. Viruses website. Available online: https://www.mdpi.com/journal/Viruses.

14. Forests website. Available online: https://www.mdpi.com/journal/Forests.

15. Foods website. Available online: https://www.mdpi.com/journal/Foods.

16. Catalysts website. Available online: https://www.mdpi.com/journal/Catalysts.

17. Genes website. Available online: https://www.mdpi.com/journal/Genes.

18. Metals website. Available online: https://www.mdpi.com/journal/Metals.

19. Processes website. Available online: https://www.mdpi.com/journal/Processes.

20. Microorganisms website. Available online: https://www.mdpi.com/journal/Microorganisms. 
21. MDPI. History of MDPI. Available online: https://www.mdpi.com/about/history (accessed on 23 December 2019).

22. Publons. Journals and Conferences. Available online: https://publons.com/journal/?order_by=num_reviews_ last_one_year (accessed on 23 December 2019).

(c) (1)

(C) 2020 by the author. Licensee MDPI, Basel, Switzerland. This article is an open access article distributed under the terms and conditions of the Creative Commons Attribution (CC BY) license (http://creativecommons.org/licenses/by/4.0/). 